KS. DARIUSZ PATER

Uniwersytet Kardynała Stefana Wyszyńskiego w Warszawie

\title{
NADZIEJA JAKO PROFIL OPIEKI NAD OSOBAMI PRZEWLEKLE CHORYMI W ZOL ${ }^{1}$
}

\author{
A nadzieja zawieść nie może, \\ ponieważ mitość Boża rozlana jest w sercach naszych \\ przez Ducha Świętego, który zostat nam dany...
}

$(\mathrm{Rz} 5,5)$

Od połowy ubiegłego stulecia problematyka nadziei znalazła się w kręgu zainteresowania wielu różnych dyscyplin naukowych, wśród których są m.in. antropologia, filozofia, psychologia, socjologia, gerontologia, teologia czy medycyna. Znawcy przedmiotu postrzegają nadzieję jako swoisty fenomen psychiczny, znaczącą siłę sprawczą, determinującą zachowania człowieka w różnych obszarach jego działalności². Zasadne więc wydaje się przedstawienie zakresu pojęciowego nadziei, jej struktury i roli, jaką odgrywa w życiu ludzi.

NADZIEJA - WYJAŚNIENIA DEFINICYJNE,

STRUKTURA I JEJ MIEJSCE W PSYCHICE JEDNOSTKI

Nadzieja jest pojęciem wieloznacznym i trudnym do zdefiniowania. Jak stwierdza Piotr Kwiatek, w różnych dyscyplinach nauk istnieje około 20 teorii nadziei i blisko 50 bardzo zróżnicowanych jej definicji ${ }^{3}$. Tenże autor, powołując się na

Zakłady Opiekuńczo-Lecznicze.

2 Por. K. Uzar, Fenomen nadziei w Wojciecha Chudego filozofii wychowania, „Roczniki Pedagogiczne" 37(2009), t. 1, s. 51-52. Szerzej na ten temat: T. Frąckowiak, O pedagogice nadziei. Fascynacje i asocjacje aksjologiczne, Wydawnictwo Naukowe UAM, Poznań 2007.

3 Por. P. Kwiatek, Znaczenie i rozwój psychologii nadziei w ujęciu Charlesa Richarda Snydera, „Seminare” 2012, t. 31, s. 158. 
Charlesa R. Snydera ${ }^{4}$, przedstawia nadzieję jako element psychologii pozytywnej, skupiającej swoją uwagę na mocnych stronach człowieka. Sytuuje ona nadzieję wśród takich pojęć, jak: dobrostan, optymizm, uskrzydlenie, przebaczenie, spełnienie czy wdzięczność ${ }^{5}$. Czesław Nosal, który uznaje nadzieję za uczucie, podkreśla, że jest ono wielce złożone. Jego zasadniczą własnością są składowe emocjonalne i czynniki, zarówno pozytywne, jak i negatywne ${ }^{6}$. Rozciąga się ona między obecnym stanem, ocenianym jako niezadowalający, a przyszłym, oczekiwanym, który ma znieść przeżywany obecnie dyskomfort. Jest nadzieja czymś głęboko osobistym, nawet intymnym. Jest też zjawiskiem ponadjednostkowym, które może być przeżywane zbiorowo. Zdaniem Małgorzaty Kościelskiej nadzieja to fenomen życia psychicznego, społecznego i duchowego każdego człowieka, ale też i całych grup społecznych, który jest jednocześnie potrzebą i motywem działania. Nadzieja angażuje emocje, pozwala przewidywać, wartościować i modelować przyszłość, choć sama również podlega przeobrażeniom ${ }^{7}$. Już w tym podejściu widać, że nadzieja ma istotne znaczenie poznawcze tak dla jednostki, jak i dla grup społecznych. Jest swoistego rodzaju prekognicją emocjonalną nakierowaną na zaistnienie pożądanego stanu, przewidywaniem jego realizacji niosącej zadowolenie z życia albo jakiegoś jego aspektu. Jeszcze wyraźniej wyraża to Józef Kozielecki, który definiuje nadzieję jako wielowymiarową strukturę poznawczą. Jej centralnym składnikiem miałoby być przekonanie, że w przyszłości człowiek osiągnie ważny dla niego cel ${ }^{8}$. Józef Kozielecki wskazuje cztery rodzaje nadziei, wyróżniając nadzieję pasywną (występująca u osób biernych, ale przekonanych, że osiągną pożądany cel), nadzieję aktywną (polegającą na wykorzystywaniu posiadanych zdolności i dyspozycji psychicznych do realizacji wyznaczonych celów), nadzieję partykularną (odnoszącą się do prostych celów własnych, jak i tych skomplikowanych ogólnoludzkich) oraz nadzieję generalną, którą nazywa również ogólną lub absolutną (niepowiązaną z konkretnym zamierzeniem, lecz trwałym przeświadczeniem, że przyszłość przynosi coraz to nowe zadania) ${ }^{9}$.

Józef Kozielecki traktuje nadzieję jako usytuowany w przyszłości naturalny stan egzystencji ludzkiej, posiadający sformułowany cel ${ }^{10}$. Właśnie ze względu na cel można mieć nadzieję na coś albo pokładać nadzieję w kimś lub czymś. Warto w tym miejscu przypomnieć, że człowiek jest istotą niezwykle skomplikowaną,

4 Ch.R. Snyder (1944-2006), amerykański psycholog, znawca psychologii klinicznej, społecznej, osobowościowej oraz psychologii zdrowia.

5 Por. P. Kwiatek, dz. cyt., s. 159.

6 Por. Cz.S. Nosal, Nadzieja, czas i heurystyka żagla, w: Człowiek wobec wyzwań i dylematów wspótczesności, red. E. Aranowska, M. Goszczyńska, Wydawnictwo Naukowe Scholar, Warszawa 2006, s. 232-233.

7 Por. M. Kościelska, Nadzieja w życiu ludzi, Difin, Warszawa 2013, s. 13.

8 Por. J. Kozielecki, Psychologia nadziei, Wydawnictwo Akademickie Żak, Warszawa 2006, s. 37.

9 Por. tamże, s. 37-42.

10 Por. tamże, s. 31. 
zarówno w swej fizycznej budowie, psychice, postępowaniu czy funkcjonowaniu na różnych poziomach. Uczestniczy on w życiu społecznym, kulturze, sztuce, religii, dzieląc się z innymi własnym doświadczeniem, zdobytą mądrością i wiedzą. Dzięki nadziei życie człowieka nabiera sensu w każdym z tych aspektów. Poprzez nią człowiek reguluje swe kontakty ze światem, a ją samą kieruje na różne obszary - te indywidualne, takie jak zdrowie, wiara, miłość, kariera, sukces, potomstwo - i te zbiorowe, odnoszące się do pokoju, powszechnego dobrobytu czy wzajemnego szacunku.

Samoświadomość podmiotu, jego ocena rzeczywistości istniejącej oraz stanu pożądanego są elementami koniecznymi do zaistnienia nadziei. Małgorzata Kościelska uważa, że nadzieja potrzebuje znajomości własnej, wewnętrznej orientacji, bo tylko wtedy jednostka może wyartykułować własne oczekiwania, uświadomić sobie pragnienia. Sama nadzieja ma bowiem moc niezwykłą i potrafi wygenerować olbrzymią energię mobilizacyjną, umożliwiającą osiągnięcie jakiegoś dobra, co w walce, np. z chorobą przewlekłą, staje się niezbędnym czynnikiem „zwycięstwa”. Kierunkuje wówczas działanie, które stanowi podstawę jej spełnienia, dając jednocześnie człowiekowi siłę, by realizować cele. Małgorzata Kościelska uważa, że nadzieję każdy postrzega inaczej. Jedni raczej negują, inni podkreślają jej sens, a to w dużym stopniu zależy od osobowości człowieka, religii, przynależności społecznej. Najważniejsze, według autorki, że dotyczy ona istotnych dla każdego wartości, przychodzi od ludzi, kierowana jest na ludzi, ma zróżnicowany wymiar czasowy, różny stopień nasilenia, potrafi się dzielić i przenosić na innych oraz zmieniać ${ }^{11}$.

Warto spojrzeć na naturę chrześcijańskiej nadziei i poznać jej źródła. Chrześcijańskie pojmowanie optymizmu i nadziei ma swój punkt wyjścia w Chrystusie i w prawdzie o zbawieniu w Nim objawionej. Różni się więc zasadniczo od czysto świeckiego pojmowania nadziei, którego podstawę stanowi zaufanie do własnych możliwości i umiejętności korzystania z nich. Nadzieja chrześcijańska wywodzi się z wiary i dotyczy przyszłości eschatologicznej, jako daru Boga ${ }^{12}$. Podobnie, jak w rozumieniu psychologów, chrześcijańska nadzieja dotyczy przyszłości, dobra, które staje się udziałem człowieka w chwili zawierzenia własnej osoby i doświadczanego losu Bogu oraz gwarancji przyszłego zbawienia. Takie bezgraniczne oddanie wydaje się pozornie rezygnacją $z$ własnych decyzji i aktywnego działania, jednak człowiek w akcie chrześcijańskiej nadziei świadomie oddaje siebie miłości Bożej. Oznacza to, że nadzieja nie tylko nie wyklucza wolnej decyzji i działania, ale je zakłada. Dzięki temu nieustannie towarzyszy człowiekowi poprzez wiarę, miłość i trwanie w żywej wspólnocie, w komunii Kościoła. Fun-

11 Por. M. Kościelska, dz. cyt., s. 12-13.

12 Por. Cz. Rychlicki, Wiara, nadzieja, miłość wobec wieczności: z zagadnień wspótczesnej eschatologii, Płocki Instytut Wydawniczy, Płock 2001, s. 124-125. 
damentem chrześcijańskiej nadziei jest bezgraniczna miłość do Boga, realizowana w Chrystusie, zapoczątkowana mocą Ducha Świętego, obecnego w sercach ludzi poprzez łaskę i ufność w przyszłe zmartwychwstanie, a także uczestnictwo w chwale Chrystusa ${ }^{13}$.

Podsumowaniem można uczynić definicję określającą nadzieję jako „wielowymiarową siłę życiową wyrażoną poprzez oczekiwanie osiągnięcia w przyszłości czegoś dobrego, co dla osoby mającej nadzieję jest możliwe i personalnie znaczące" 14 .

\section{ROLA NADZIEI \\ W SKOMPLIKOWANYCH SYTUACJACH ŻYCIOWYCH CZŁOWIEKA}

Człowiek w swym życiu doświadcza wielu różnych zdarzeń, tych pozytywnych ale także trudnych, skomplikowanych, nazywanych też krytycznymi, wpływających znacząco na przebieg i jakość życia. W klasycznym rozumieniu zakłócają one wewnętrzną równowagę, zaburzają normalny przebieg aktywności, obniżając jednocześnie realizację zadań na dotychczasowym poziomie ${ }^{15}$. Niektóre z nich wynikają ze zdarzeń losowych, inne zaś z różnorodnych procesów, ale w gruncie rzeczy wszystkie zaburzają pożądane funkcjonowanie człowieka, determinując różnorodność zachowań, rodząc też niekiedy wiele nowych wyzwań. Należy pamiętać, że zdrowie nie wyczerpuje listy trudnych sytuacji, które dotyczyć mogą też np. ubóstwa, sieroctwa, przemocy w rodzinie, utraty bliskich osób, bezdomności, bezrobocia, niepełnosprawności, macierzyństwa, uzależnień (alkoholizmu i narkomanii) czy ograniczenia wolności.

W tym kontekście warto poruszyć problematykę tzw. „radzenia sobie”, polegającego m.in. na umiejętności przystosowania się do kłopotów i zawirowań, jakie przynosi życie. W przypadku ludzi starszych takim zadaniem rozwojowym staje się np. akceptacja starości, uznanie swojej ułomności, obniżonej sprawności lub choroby ${ }^{16}$. Nie jest to oczywiście łatwe, ale i w tym przypadku istotną rolę odgrywa nadzieja i przyjęcie odpowiedniej postawy wobec zaistniałych zjawisk. Wszystko zależy od konstrukcji wewnętrznej danej jednostki, jej psychiki, temperamentu, emocjonalnego nastawienia czy umiejętności radzenia sobie z niepowodzeniami

13 Por. tamże, s. 132.

14 J. Chaplin, R. McIntyre, Hope: an exploration of selected literature, w: Palliative nursing: bringing comfort and hope, red. S. Kinghorn, R. Gamlin, Bailliere Tindall, Edinburgh 2001, s. 119.

15 Por. T. Tomaszewski, Człowiek i otoczenie, w: Psychologia, red. T. Tomaszewski, PWN, Warszawa 1975, s. 32.

16 Por. B. Szatur-Jaworska, Ludzie starzy i starość w polityce spotecznej, Aspra-Ir, Warszawa 2000, s. 46. 
i ułomnością. Warto też pamiętać o kulturowym otoczeniu człowieka oraz bardzo zróżnicowanych, w konkretnych przypadkach osób, czynnikach zewnętrznych. To właśnie środowisko jednostki odgrywa niezwykle istotną rolę w jej codziennym funkcjonowaniu, bowiem jego zasoby, obok potencjału indywidualnego (m.in. samoakceptacji, zaufania do siebie, umiejętności przystosowania się, odporności i dojrzałości psychicznej, zrównoważenia emocji), determinują postawy osób starszych wobec siebie, wobec innych i wobec podejmowanych działan ${ }^{17}$.

Obserwacje własne, pozwalają na wskazanie odmiennych zachowań, prezentowanych przez osoby starsze, przewlekle chore czy niepełnosprawne. Zauważyć można postawę konstruktywną, aktywną, przejawiającą się w pogodnym i racjonalnym traktowaniu doświadczanych zdarzeń, pogodzeniu się ze starością, a nawet zbliżającą się śmiercią i oczekiwaniu na nią z ufnością, bez żalu i rozpaczy. Jej przeciwieństwem jest postawa zależności, charakteryzująca się biernością i wycofaniem, przy jednoczesnym uzależnianiu swego funkcjonowania od obecności innych i ich wsparcia, gwarantującego bezpieczeństwo i poczucie wewnętrznej harmonii. Często trudna dla otoczenia jest obronna postawa ludzi starszych, wynikająca z potrzeby niezależności i jednocześnie ogromnych lęków przed niesprawnością, kalectwem, ciężką chorobą i śmiercią. Te właśnie obawy ukrywane są pod maską aktywności i podejmowanych różnorodnych czynności. Wrogość, prezentowana przez osoby starsze, kierowana bywa na innych lub bezpośrednio na własną osobę. W pierwszym przypadku występuje tendencja do użalania się nad sobą i oskarżania innych, demonstrowania gniewu i buntu przeciwko chorobie czy starości, przy jednoczesnym braku optymizmu, nadziei i motywacji do zmian. Niechęć kierowana na siebie wynika często z ujemnego bilansu życia, samotności, silnie odczuwanej bezradności, niedowartościowania, głębokiego poczucia krzywdy, braku sensu i celu życia oraz postrzegania śmierci jako wybawienie $z$ dotychczasowych trosk, choroby i udręk, nieraz wyimaginowanych ${ }^{18}$. Wspólne dla wyżej wymienionych postaw wydają się też takie zachowania jak zmniejszone poczucie stabilności i bezpieczeństwa, bezradność, pustka życiowa i poczucie beznadziei, apatia, zmienny nastrój, gwałtowne reakcje, niewspółmierne do sytuacji, zaburzenia myślenia i jasnego wyrażania myśli, chaos w działaniu i utrata woli życia, oczywiście w różnych konfiguracjach i zróżnicowanym natężeniu. Ta różnorodność postaw determinuje określone traktowanie ze strony środowiska, w którym funkcjonują osoby starsze czy chore. Nie może to być jednak silna interwencja ograniczająca prawa tych osób lub bezwzględnie narzucająca im sposób działania. Należy pamiętać o uznaniu wszystkich praw osób chorych czy

17 Por. A. Brzezińska, Społeczna psychologia rozwoju, Scholar, Warszawa 2000, s. 65.

18 A.A. Zych, Człowiek wobec starości. Szkice z gerontologii społecznej, Śląsk, Katowice 1999, s. $145-147$. 
starszych, w takim samym stopniu, w jakim respektowane są one w przypadku osób młodych czy całkiem sprawnych.

Człowiek, bez względu na wiek, pragnie być szczęśliwy i wieść życie pełne zadowolenia. Literatura podejmuje problematykę jakości życia, skupiając się w tym zakresie na ogólnym stanie zdrowia, sprawności funkcjonalnej, poczuciu ogólnego komfortu życiowego, stanu psychicznego (emocjonalnego) oraz sytuacji ekonomicznej jednostki ${ }^{19}$. Niezależnie też od wieku człowiek snuje plany, marzy i ma nadzieje na coś lub wobec kogoś. I choć wiek (starość) wydaje się ograniczać możliwości planowania, to nie jest to obce ludziom chorym, niepełnosprawnym czy starszym. Bo przecież, mimo wielu ograniczeń, nawet człowiek schorowany czy niedołężny, pragnie szczęścia i może być szczęśliwy. Ważne w tym przypadku jest posiadanie wokół siebie rodziny lub życzliwych i pogodnych osób obcych. Tylko w takich warunkach możliwe wydaje się utrzymanie poziomu pewnej sprawności intelektualnej i fizycznej, radości życia, poczucia spełnienia i przynależności oraz skupienia się na sobie i własnych potrzebach. Niezwykle istotne wydaje się również funkcjonowanie osoby przewlekle chorej lub starszej w gronie innych osób, które darzy ona zaufaniem. To osoby z najbliższego otoczenia winny budować kontakt, pamiętając o szacunku, odpowiedzialności i zaangażowaniu odpowiednim dla potrzeb konkretnej jednostki. Zaufanie, to szczególny rodzaj wzajemnych relacji między ludźmi, a chorzy i starzy ludzie z reguły bywają nieufni lub ufają nadmiernie, co wynika z ich życiowych doświadczeń lub postępującej starości i choroby. Chcąc pozyskać ich sympatię i zaufanie należy poświęcać im uwagę i czas, angażować się, odwzajemniać uczucia i relacje, respektować zasady, przestrzegać wartości i pamiętać, że nie istnieją substytuty zaufania. Trudne sytuacje życiowe wiążą się bezsprzecznie z nadzieją, która wyrasta na gruncie tęsknoty, pragnień i ufności w dobro, jest nieustannie poddawana próbom, ale dopóki człowiek jej doświadcza - żyje i stara się pokonać trudności. Dopóki ma nadzieję, mierzy się z przeciwnościami losu. Jest więc nadzieja lekarstwem na ból, strach i zniechęcenie, stanowi czynnik niezbędny do zmian, dodaje otuchy i radości, udoskonala - zawsze niedoskonałe życie.

Co jednak zrobić, gdy nadzieja się chwieje? Strategii bywa wiele i chociaż to trudne zadanie, konieczne wydaje się odszukanie wcześniejszych zasobów, inwentaryzacja sił i słabości, poszukiwanie „osobistego pakietu nadziei” poprzez „odkurzanie” zaniedbanych kompetencji, np. umiejętności wyrażania emocji. Ważne jest przy tym usłyszenie zachęty do współpracy z innymi, i słów motywujących do pokonywania przeszkód. Czymże więc ostatecznie jest nadzieja? Jak powiedział Jan Twardowski: „Nieraz nam się wydaje, że nadzieja jest łatwą optymistką, patrzącą na świat przez różowe okulary. Tymczasem nadzieja jest także dramatem,

19 T. Gałkowski, Nowe podejście do niepetnosprawności. Uporządkowanie terminologiczne, ,Audiofonologia" 1997, nr 10, s. 161. 
ciągłą walką pomiędzy budowaniem na samym sobie, na swoich obliczeniach i pomysłach, i na budowaniu na Panu Bogu"20.

\section{DEUGIE ŻYCIE CZŁOWIEKA I WYZWANIA Z NIM ZWIAZZANE}

Ludzkie życie ma wiele wymiarów, z których przeszłość, teraźniejszość i przyszłość wydają się być oczywiste. Człowiek wiąże z nimi różne odczucia. Mowa oczywiście o dzieciństwie, młodości, dojrzałych latach życia i wieku podeszłym, oglądanych z różnych perspektyw. Warto jednak zauważyć, że to przyszłość postrzegana jest zawsze jako najbardziej niepokojący wymiar egzystencji. $O$ tej nierozpoznanej przyszłości można mówić w każdym wieku, ale najwięcej niepokojów zawsze budzi starość, od jakiegoś czasu znajdująca się w kręgu zainteresowania wielu dziedzin nauki. Wpływ na to ma oczywiście fakt wzrastającej populacji osób starzejących się i starych, nie tylko w naszym kraju ${ }^{21}$, ale także w całej Europie i świecie. Ostatnie dziesięciolecia przyniosły ogromne zmiany nie tylko w strukturze demograficznej, ale i w samym biologicznym wymiarze procesu starzenia się. Postęp medycyny, rozwój różnorodnych technologii, które znalazły zastosowanie $w$ tej dziedzinie, stale rosnąca świadomość profilaktyki, a także zdrowe nawyki higieniczne i żywieniowe spowalniają proces starzenia się ludzi. Efektem tego, dla znacznej grupy osób, jest sprawniejsze funkcjonowanie w starości ${ }^{22}$. Cieszyć więc może fakt coraz dłuższego życia oraz lepsza jego jakość wśród seniorów. To w dużej mierze skutek postępów dokonanych w medycynie. $\mathrm{Z}$ drugiej strony daje się zaobserwować zjawisko rozpraszania prestiżu starości, jej deprecjacja, nieraz nawet gerontofobia, czyli wrogi stosunek do ludzi starszych $^{23}$. Warto więc postawić pytanie: Czym właściwie jest starość? Literatura udziela na nie wielu, $i$ to różnorodnych, odpowiedzi. Biologia i medycyna nazywają tę fazę okresem życia ustroju po wieku dojrzałym. Wiąże się on z szeregiem zmian zachodzących w organizmie, przede wszystkim z obniżeniem funkcji życiowych ${ }^{24}$.

Prawdą jest, że coraz więcej osób tzw. trzeciego i czwartego wieku czy „ludzi złotej jesieni" jest sprawnych i aktywnych. Jest jednak wśród ludzi starszych duża grupa osób przewlekle chorych, zniedołężniałych, wymagających stałej troski i opieki. Ten stan stwarza różnorodne problemy społeczne. Dotyczą one nie tylko

20 J. Twardowski, Kilka myśli o wierze, nadziei i miłości, Wydawnictwo Święty Wojciech, Poznań 2006, s. 12.

21 Według prognozy GUS na rok 2020 odsetek osób starych w populacji ma osiągnąć $22,4 \%$, a co czwarty z nich przekroczy 75 . rok życia.

22 Por. R.J. Kijak, Z. Szarota, Starość. Między diagnoza a działaniem, Centrum Rozwoju Zasobów Ludzkich, Warszawa 2013, s. 12.

23 Por. A.A. Zych, dz. cyt., s. 13.

24 Por. R.J. Kijak, Z. Szarota, dz. cyt., s. 14. 
osób bliskich starszym osobom chorym lecz również osób czujących moralny obowiązek wspierania tych najbardziej potrzebujących. Problemy te dotyczą wszystkich podatników. Problem starzejących się społeczeństw narasta, stając się wyzwaniem ekonomicznym i społecznym, co wymaga podejmowania wieloaspektowych badań i działań przez rządy oraz organizacje. Naukowcy podkreślają, że rozwiązanie czy złagodzenie wielu problemów starości wiąże się z postępem w dziedzinie profilaktyki, diagnostyki i leczenia. Nie bez znaczenia są innowacje w medycynie, które mogą poprawiać wskaźniki zdrowotne, w tym aktywność i ogólne zdrowie ludzi w podeszłym wieku, i uniknąć potrzeby korzystania z placówek szpitalnych, zakładów opiekuńczo-leczniczych czy innych ośrodków opieki długoterminowej.

Bezwzględna liczba seniorów w Polsce rośnie, co przekłada się na wzrastające również obciążenia systemu ochrony zdrowia kosztami leczenia i opieki nad tymi osobami. To problemy zdrowotne, takie jak choroba, inwalidztwo i niepełnosprawność stanowią największe wyzwanie, choć trzeba też pamiętać o samotności, ubóstwie, poczuciu nieprzydatności. Populacja ludzi starszych jest ogromnie zróżnicowana przede wszystkim pod względem stanu zdrowia, a także w obszarze biologicznym, psychicznym oraz oczywiście społecznym. Wszelkie systemowe zmiany, rzutujące na życie tych osób i realizację ich potrzeb, wymagają ostatecznie indywidualnego wprowadzania.

Łagodzeniu problemów ludzi starszych nie sprzyja funkcjonujący we współczesnych społeczeństwach „kult młodości” i stereotyp człowieka starszego, pejoratywnie kojarzonego. Generuje on obojętność, brak zrozumienia, niechęć do niesienia pomocy i przeznaczania środków finansowych na potrzeby ludzi starszych. Zmienia ponadto postawy młodych wobec starszych, u tych drugich zaś zakłóca dobre samopoczucie i dobrostan ${ }^{25}$. Niestety, zjawisko ageizmu (dyskryminacji ze względu na wiek) wcale nie ulega ograniczeniu, powodując często nieuświadomiony strach przed starością, chorobami i inwalidztwem. Brak znajomości zagadnienia wynika z braków edukacyjnych, niewłaściwych wzorców rodzinnych, nieumiejętności nawiązywania kontaktów z osobami starszymi, obaw o konieczność poświęcenia się dla tej osoby, poprzez opiekę i pomoc osobie starszej, nawet bardzo bliskiej.

Warto jednak uświadamiać wszystkim, szczególnie młodym, nieuchronność starości, poprzez wprowadzenie do szkół edukacji społecznej na temat gerontologii, tolerancji oraz solidarności między generacjami, rozumianej jako wzajemna zależność. Dobrym przykładem jest propagowanie pozytywnego stereotypu np. wspaniałego dziadka czy babci, pełnych miłości, cierpliwości, wspomagających wnuki i ich potrzeby, doskonale funkcjonujących wśród dzieci i młodych ludzi.

${ }_{25}$ Por. J. Dziewulska, Przeciw pustce i beznadziejności, „Magazyn Pielęgniarki i Położnej” 2000, nr 1-2, s. 24. 
Życzliwość, wdzięczność czy tkliwość wydają się obecnie niemodne, choć przecież tak potrzebne we wzajemnych relacjach wszystkich ludzi. Jan Paweł II, sam czując brzemię choroby i starości, w Liście do ludzi w podeszłym wieku napisał: „Jeżeli dzieciństwo i młodość są czasem, w którym człowiek stopniowo uczy się człowieczeństwa i rozpoznaje swoje możliwości, to starość jest szczególną wartością, ponieważ łagodząc namiętności pomnaża mądrość i służy dojrzalszymi radami. Jest to czas szczególnie nacechowany mądrością" ${ }^{26}$. Przede wszystkim nie wolno lekceważyć problemów ludzi starszych i pozostawiać ich samych, dlatego ciągle trzeba walczyć o poprawę statusu tej grupy społecznej. Państwo, podobnie jak i wiele instytucji pozarządowych, podejmuje szereg inicjatyw, chcąc zabezpieczyć jej potrzeby, niestety w praktyce, w wielu przypadkach ogranicza się to jedynie do wsparcia finansowego, choć w różnych dokumentach programowych dostrzega się konieczność zapewnienia opieki oraz rozszerzenia form i zakresu pomocy. Należy podkreślić, że dowodem dojrzałości człowieka jest jego zachowanie wobec osoby starszej, chorej i niepełnosprawnej, a w szerokim aspekcie wspomagania tych osób szczególna rola przypada najbliższej rodzinie.

\section{POTRZEBY OSÓB}

\section{PRZEWLEKLE CHORYCH I MOŻLIWOŚCI ICH ZASPOKOJENIA}

Zdrowie to wartość niezwykle cenna i ważna w odczuciu większości ludzi. W egzystencję człowieka wpisują się jednak także i choroby, te krótkie, leczone bardzo szybko i skutecznie, a także te przewlekłe, nieuleczalne, terminalne, niedające szans na wyleczenie, postrzegane również jako forma cierpienia. Choroba i długotrwałe cierpienie jest ogromnym wyzwaniem dla pacjenta i dla jego otoczenia. Osoby chore potrzebują rzeczowego, moralnego i uczuciowego wsparcia, doświadczają bowiem same na sobie lęków i obaw o własne zdrowie i życie. Potrzebują pomocy zewnętrznej, obecności, zrozumienia, rozmowy i nadziei.

Sama diagnoza wywołuje nieraz ogromne emocje i rodzi sytuacje kryzysowe w życiu chorego i jego bliskich ${ }^{27}$. Jeśli jeszcze dotyczy choroby onkologicznej, budzi wiele negatywnych skojarzeń, które przez lata utrwaliły się w społeczeństwie. Przede wszystkim wiąże się z niepewnością rokowań, długim i bolesnym leczeniem oraz przewidywanymi cierpieniami. U wielu pacjentów pojawia się obniżona sprawność i aktywność ruchowa, złe samopoczucie, smutek, zniechęcenie, pesymizm, które dopiero później mogą wygenerować także i pozytywne emocje, wspomagające leczenie. Choroby chroniczne występują w równym stop-

\footnotetext{
26 LOPW 5.

27 Por. Praktyczny podręcznik psychoonkologii dorostych, red. M. Rogiewicz, Medycyna Praktyczna, Kraków 2015, s. 17.
} 
niu u mężczyzn i kobiet, a ryzyko ich występowania podnosi się wraz z wiekiem, dlatego też u osób starszych pojawia się zjawisko wielochorobowości. Choroba przewlekła zmienia dotychczasowy rytm życia pacjenta, zaburza jego relacje z samym sobą, własnym ciałem, nieraz „,całym światem”. Chory odczuwa ogromny dyskomfort, fizyczny i psychiczny, gubi się w codziennym funkcjonowaniu, dlatego też na otoczeniu, tym rodzinnym, medycznym i społecznym, spoczywa obowiązek niesienia pomocy, bardzo zróżnicowanej, bo i odmienny bywa przebieg choroby u poszczególnych pacjentów. Osoby chore - jak i wszyscy inni - nie są takie same, niejednakowo też przebiega u nich nawet ta sama choroba, dlatego też w przeważającej części potrzebują wszechstronnej i całościowej opieki, polegającej na wykonywaniu w sposób umiejętny wielu czynności oraz realizowaniu procesów pozwalających zachować optymalny tryb życia. Efektywność zmagania się ze schorzeniem i wywoływanym przez niego cierpieniem zależy od wielu czynników. Pamiętać należy o różnych kulturach, modelach ujmowania choroby, wzajemnych układach i powiązaniach rodzinnych czy stosunku do osób chorych. Zastosowanie znajduje w takich przypadkach koncepcja medycyny skupionej na pacjencie, gdzie jego potrzeby, osobisty stosunek do rodzaju medycznej - i nie tylko medycznej - interwencji stają się najważniejsze.

Obecnie istnieją różnorodne formy opieki nad ludźmi przewlekle chorymi. Pojawia się także coraz więcej osób dostrzegających autentyczne potrzeby ludzi ciężko, nieuleczalnie chorych, umierających i ich najbliższych ${ }^{28}$. To od nich cierpiący uzyskują ulgę fizyczną, zyskują także ich bliską obecność, jakże potrzebną w trudnych momentach choroby. Państwo nie pozostawiło tych ludzi bez opieki i określiło zasady wsparcia dla osób przewlekle chorych i korzystania ze świadczeń w ramach zakładów opiekuńczych. Odpowiednie regulacje prawne znalazły się w ustawie z dnia 27 sierpnia 2004 roku o świadczeniach opieki zdrowotnej finansowanych ze środków publicznych ${ }^{29}$, ustawie o pomocy społecznej z dnia 12 marca $2004^{30} \mathrm{i}$ w rozporządzeniu Ministra Zdrowia z dnia 22 listopada 2013 roku w sprawie świadczeń gwarantowanych z zakresu świadczeń pielęgnacyjnych i opiekuńczych $w$ ramach opieki długoterminowej ${ }^{31}$. Zakres przewidzianej tam pomocy obejmuje świadczenia pieniężne, np. zasiłek okresowy ${ }^{32}$, celowy (pokrycie m.in. kosztów leków, środków opatrunkowych) ${ }^{33}$ oraz wsparcie w postaci usług opiekuńczych.

28 Por. A. Bartoszek, Człowiek w obliczu cierpienia i umierania. Moralne aspekty opieki paliatywnej, Księgarnia Świętego Jacka, Katowice 2000, s. 19.

29 Dz.U. 2008, nr 164, poz. 1027 ze zmianami, tekst jednolity, Dz.U. 2015, poz. 581.

30 Tekst jednolity, Dz.U. 2015, poz. 163.

31 Dz.U. 2013, poz. 1480, tekst jednolity Dz.U. 2015, poz. 1658.

32 Ustawa o pomocy społecznej z dnia 12 marca 2004 r., art. 38, ust. 1.

33 Tamże, art. 39, ust. 1 i 2. 
W zakładach opiekuńczych umieszczani są pacjenci, którzy zakończyli proces leczenia szpitalnego, a niestety nie mogą przebywać w środowisku domowym, ponieważ potrzebują kontynuacji leczenia przewlekłego, pielęgnacji lub rehabilitacji. Oceny zdrowia dokonuje się skalą Barthel (chory trafia do placówki, gdy w chwili przyjęcia otrzymał 40 punktów lub mniej, nie znajduje się w fazie zaawansowanej choroby nowotworowej, nie ma też zdiagnozowanej choroby psychicznej). Podstawą działań staje się polepszenie jakości życia podopiecznych, w niektórych przypadkach doprowadzenie do stanu, w którym możliwy staje się powrót do domu. W placówkach pacjenci otrzymują opiekę wykwalifikowanych opiekunów osób starszych, pomoc lekarską i pielęgniarską, w tym specjalistyczne konsultacje, możliwość korzystania z różnych zabiegów rehabilitacyjnych, wsparcie np. logopedy czy dietetyka, opiekę psychologiczną i duszpasterską, spotkania z terapeutą zajęciowym, a także pracownikiem socjalnym. Niektóre z ośrodków dostosowują ofertę do indywidualnych potrzeb i zainteresowań podopiecznych. W każdej z ofert takich zakładów podkreślany jest profesjonalizm personelu, miła, domowa atmosfera, ciepło i życzliwość wszystkich osób posługujących chorym. Niestety, prawda w wielu przypadkach odbiega od tych deklaracji, o czym często informują media ${ }^{34}$.

Pacjent trafia do zakładu opiekuńczo-leczniczego na własny wniosek lub na wniosek przedstawiciela prawnego, po zawarciu umowy cywilno-prawnej na świadczenia opiekuńczo-lecznicze, realizowane w różnych pakietach opieki. Zdecydowana ich większość dotyczy pobytów długoterminowych i przeznaczona jest dla chorych przewlekle w różnym wieku lub dla osob starszych o ograniczonej sprawności. Poszczególne zakłady starają się zapewnić podopiecznym nowoczesny sprzęt leczniczy i rehabilitacyjny, urządzenia wspomagające wygodę i bezpieczeństwo osób o ograniczonej sprawności, np. systemy przywoławcze i alarmowe, windy, podnośniki kąpielowe, wózki, chodziki i balkoniki inwalidzkie oraz nadzór wizyjny w części sal. Proponują też coraz częściej małe pokoje z komfortowym wyposażeniem oraz z wyżywieniem, uwzględniającym zalecane diety i kulinarne preferencje osobiste. W Polsce funkcjonuje blisko 400 zakładów opiekuńczo-leczniczych. Instytucje tego typu prowadzą różne podmioty, poczynając od publicznych jednostek samorządu terytorialnego, przez kościoły i związki wyznaniowe, organizacje pozarządowe, społeczne, a także osoby prawne i fizyczne ${ }^{35}$. Potrzeby przerastają jednak możliwości istniejących placówek. Stowarzyszenie Organizatorów i Promotorów Opieki Długoterminowej szacuje, że ośrodków takich winno być przynajmniej trzykrotnie więcej ${ }^{36}$.

\footnotetext{
34 www.niepelnosprawni.pl/ledge/x/17796 (20.5.2017).

35 P. Sikora, Ośrodki wsparcia dziennego, w: Formy opieki, wychowania i wsparcia w zreformowanym systemie pomocy spotecznej, red. J. Brągiel, S. Badora, Wydawnictwo Uniwersytetu Opolskiego, Opole 2005, s. 565.

36 Tamże.
} 


\section{NADZIEJA U LUDZI OBJĘTYCH OPIEKĄ W PLACÓWKACH ZOL}

Choroba przewlekła budzi wiele negatywnych emocji, takich jak strach, złość czy negacja, ale często po pierwszym szoku pojawia się akceptacja i próby przystosowania się do życia z dysfunkcją. Każdy oswaja się z tym faktem w inny sposób i w bardzo różnym czasie, przewartościowując swoje dotychczasowe życie, zmieniając priorytety i odkrywając jakoby na nowo to, co jest naprawdę najważniejsze. Istotna rola w tym obszarze przypada także lekarzom, którzy mają w przypadku choroby najbliższy kontakt z chorym. Ważne są wzajemne relacje, stosunek do chorego, sposób przedstawienia diagnozy i rozmowy o rokowaniach. To lekarze muszą tak pokierować rozmową, by umiejętnie przekazać nie zawsze pomyślne wieści. Nie można bowiem przekazywać prawdy bez nadziei i nadziei bez prawdy. Jak trudnym jest to wyzwaniem, świadczą wypowiedzi lekarzy, którzy potwierdzają, że bez względu na staż pracy i doświadczenie w kontaktach z pacjentami terminalnymi, zawsze podświadomie mają problem z przekazaniem złych wiadomości pacjentowi i jego najbliższym.

JAN (64 lata, staż lekarski 32 lata) ${ }^{37}$

„Od 32 lat jestem lekarzem ze specjalizacją chirurgiczno-onkologiczną. To, że zostałem lekarzem wynikało z tradycji rodzinnych. Lekarzami byli dziadkowie, rodzice, no i żonę także znalazłem w tym środowisku.

Swej pracy poświęcam wiele, zdaniem najbliższych robię to ich kosztem, ale pacjenci to przecież także moja rodzina. Tym bardziej że jest to grupa tych dotkniętych najcięższymi chorobami. Staram się pomagać, choć nieraz staję bezsilny w obliczu cierpienia i śmierci. Zdarza się, że stawiając diagnozę sam odczuwam ból, cierpię i współczuję swoim pacjentom.

Zawsze też staram się być na tyle delikatny, by nie przekreślać szans na wyleczenie, sam żywię nadzieję na wyleczenie i nie chcę jej odbierać innym. Podkreślam, że nadzieja w takim przypadku jest niezbędna, chociaż należy być przygotowanym też na najgorsze".

ADAM (35 lat, staż lekarski 8 lat) ${ }^{38}$

„Choroba, pacjent, nadzieja i ja. To naprawdę wyjątkowo trudne znaleźć się w takiej sytuacji. Kilka lat pracy a ja ciągle zastanawiam się, jak rozmawiać $\mathrm{z}$ chorym. I ciągle też mam pretensje, że nie nauczono mnie na studiach technik, które pomogłyby mi przekazywać złe wiadomości.

37 Własny wywiad pogłębiony, niepublikowany, przeprowadzony w czerwcu $2017 \mathrm{r}$.

38 Własny wywiad pogłębiony, niepublikowany, przeprowadzony w maju $2017 \mathrm{r}$. 
Ciągle bije się z myślami jak to robić, rozmawiam ze starszymi kolegami, ale i oni borykają się z tym problemem i mimo upływu lat uczą się tej szczególnej umiejętności. Sam nieraz zastanawiam się, co zrobiłbym będąc pacjentem. Chyba chciałbym prawdy, choć sam nieraz przekazując informacje dotyczące rokowań uciekam wzrokiem, koncentruję się na badaniach czy innej dokumentacji, by choć na chwilę odwlec to, co nieuniknione.

Uspokajam, opowiadam o dalszym leczeniu, mówię o różnych terapiach i nadziei, którą zawsze trzeba mieć. I ja ją mam, chcę by mieli ją też moi pacjenci, bo nadzieja i wiara czynią naprawdę cuda (...)".

Wielu chorych koncentruje się w takiej sytuacji na rodzinie, bliskich i przyjaciołach, znajdując przyjemność w obcowaniu z innymi. To w nich znajdują wsparcie i siły do walki z chorobą.

\section{STANISŁAW (62 lata) $)^{39}$}

„Zawsze byłem bardzo aktywny i nie poddawałem się kłopotom. Nie miałem też żadnych problemów zdrowotnych, kiedy więc podczas rutynowych badań coś zaniepokoiło mojego lekarza, nie byłem tym w ogóle przestraszony. Nawet kiedy trafiłem do szpitala, patrzyłem w przyszłość bez żadnych obaw. Diagnoza była zaskoczeniem, wada serca, konieczność przerwania pracy, zwolnienia trybu życia, później sanatorium poszpitalne i na rok przyznana renta. To dopiero uświadomiło mi, że sytuacja jest poważna, tym bardziej że mój ojciec i dwóch braci zmarło na serce. Na pewien czas trafiłem do placówki ZOL. Najbliżsi stali się po prostu nadopiekuńczy, co dodatkowo pogarszało moje samopoczucie. Dopiero rozmowy z psychologiem pomogły mi odnaleźć się w nowej sytuacji.

Cieszę się z opieki żony i dzieci, stosuję wszystkie wskazania lekarskie i mam nadzieję na jeszcze wiele lat wspólnego życia z nimi. Mam nieraz czarne myśli, ale to właśnie obecność rodziny zmienia pozytywnie moje nastawienie”.

Pobyt w placówce leczniczej zawsze jest stresujący. Bywają jednak i takie sytuacje, kiedy człowiek sam się zgłasza do ZOL lub DPS. Jak dowodzą badania, takie osoby znacznie lepiej aklimatyzują się do panujących tam warunków, niż te, które umieszczane są tam wbrew swojej woli.

KRYSTYNA (89 lat) ${ }^{40}$

„Mam wspaniałą rodzinę, chociaż z biegiem lat wykruszają się najbliżsi.

Ponad 20 lat temu straciłam męża, którego pokonała ciężka choroba i kilka lat

\footnotetext{
39 Własny wywiad pogłębiony, niepublikowany, przeprowadzony w maju $2017 \mathrm{r}$.

40 Własny wywiad pogłębiony, niepublikowany, przeprowadzony w czerwcu $2017 \mathrm{r}$.
} 
temu jedną z czterech córek, zmarłą po powikłaniach powypadkowych. Niecały rok temu odeszła kilka lat młodsza moja siostra. Zawsze ufna w Bogu znosiłam to, co przeznaczyło mi życie. Niestety, mijające lata ograniczyły moją sprawność, szczególnie wzrok, ale dzieci pomagały mi jak tylko mogły. Zauważyłam, że i im przybywa lat, co stanowi też pewne ograniczenie. A przyjazd do mnie wymagał od nich wiele, bo nie mieszkały w tej samej miejscowości, choć odległości nie były ogromne.

To była niespodziewana decyzja, za namową koleżanki odwiedziłyśmy placówkę ZOL w niedalekiej od naszej miejscowości. Rozmawiałyśmy z kierownictwem, personelem pielęgniarskim i pensjonariuszami, no i podjęłyśmy decyzję. Wspólną, bo razem naprawdę raźniej.

Kilka miesięcy temu opuściłam swój dom. Świadomie i (...) jestem naprawdę zadowolona. Mam opiekę i żywię głęboką nadzieję, że będę mieszkać jeszcze długi okres tu, gdzie mam zapewnioną naprawdę właściwą opiekę lekarską i pielęgniarską. Nie zawsze decyzja o pobycie w takiej placówce jest zła”.

Droga do radości bywa ciernista i ciemna, czego przykładem są przypadki zupełnie odmienne, choćby pani Barbary, której egzystencję nadal oświetla nadzieja.

\section{BARBARA (72 lata) $)^{41}$}

„Nie chcę tu być i nigdy nie chciałam. To na pewno decyzja mojej synowej, bo syn jest taki uczuciowy, ale jednocześnie słucha tylko żony. A miało być tak pięknie. Wybudowaliśmy nowy duży dom, dla nas i przyszłej rodziny syna. Później w wypadku zginął mój mąż, a ja doznałam bardzo ciężkich złamań i wymagałam stałej opieki.

Przez kilka tygodni przebywałam w szpitalu na oddziale ortopedycznym, a od kilku miesięcy jestem lokatorką ZOL. Nie jest mi źle, ośrodek jest zadbany, a pielęgniarki i rehabilitant naprawdę życzliwi, ale przecież moje miejsce jest wśród najbliższych. Ja też pomału odzyskuje sprawność fizyczną. Wiem, że nadal potrzebuję rehabilitacji, ale moi najbliżsi mogliby to zorganizować inaczej. Synowa nie pracuje zawodowo, nie mają dzieci, to przecież może mnie wspomagać. Ona po prostu nie chce, buntuje też syna, a on nie potrafi się jej przeciwstawić. Nie tracę nadziei, że to się zmieni, tak pragnę wrócić do domu. Każdy nowy dzień rozpoczynam myślą, iż moja synowa zrozumie, że też będzie kiedyś potrzebowała wsparcia".

Osoba starsza i schorowana, przebywająca w ZOL, wymaga kontaktów z rodziną, opiekunami, nieraz przyjaciółmi, szczególnie jeśli kontakty te były

${ }^{41}$ Własny wywiad pogłębiony, niepublikowany, przeprowadzony w czerwcu $2017 \mathrm{r}$. 
wcześniej systematyczne. Tak ważny jest wówczas oddany chorym czas, opieka i szacunek, szczególnie w przypadku, gdy pojawia się u nich gorycz starzenia się i obawa przed bezradnością.

\section{DANUTA (73 lata)}

„Pracowałam z ogromnym zapałem, lubiłam swą pracę, choć chyba głównie goniłam za różnymi dobrami materialnymi. Zawsze było wokół mnie mnóstwo osób, nawet wówczas, gdy wyjechałam do Stanów, by zarobić dla dzieci.

Kilkuletni pobyt zakończył się sukcesem, wybudowałam domy, wyposażyłam dzieci i wnuki, ale zachorowałam. Odezwały się wcześniej zdiagnozowane schorzenia, przybyło nowe RZS (reumatoidalne zapalenie stawów). To dało się we znaki, wykrzywiło ręce tak, że nie zawsze jestem w stanie podnieść kubek czy zapiąć guzik bluzki. Ponadto silne bóle ograniczają codzienne funkcjonowanie.

Rodzinna narada i znalazłam się w placówce. Tymczasowo, ale czy na pewno? Miały być stałe kontakty, odwiedziny, wspólne spędzanie czasu. Niestety, zniknęłam z rodziny i jakoś o mnie zapomniano. Czuję się opuszczona, samotna, odcięta od tego, co jest mi drogie. Borykam się z bólem fizycznym i wewnętrznym cierpieniem. Wszystko to razem to ciężar, który naprawdę uwiera. Nie, jeszcze nie straciłam nadziei, przecież dopóki trwa życie, dopóty jest nadzieja (...)".

\section{MARIA (85 lat)}

„Ja nie mam bliskich, wszyscy odeszli, więc kiedy dotknęła mnie choroba, naturalną drogą trafiłam do ZOL. A przyszła ona niespodziewanie i była z tych najgorszych. Lekarz powiedział mi wszystko bez ogródek, co wywołało u mnie ogromną bezsilność, może nawet złość. Chyba powinien to zrobić delikatniej. On po prostu stwierdził: jest pani osobą świadomą i nie będę owijał w bawełnę. Ogarnęło mnie przerażenie, tym bardziej że powiedział to na sali pełnej chorych. Popatrzyłam na niego bezradnie i zamiast martwić się sobą, zastanawiałam się, dlaczego wybrał ten zawód, skoro nie ma w nim cienia empatii.

Jestem pensjonariuszką ZOL, mam wokół siebie wiele bardziej życzliwych osób niż ten lekarz. Jakie są rokowania? Wiem, że bardzo niepewne. Ponadto ból stał się moim wiernym towarzyszem od prawie dwóch lat. Nie są mi obce chwile zwątpienia, mam dość cierpienia, a jednocześnie mam nadzieję na być może coś nieosiągalnego (...) nowy skuteczny lek czy cud. W trudnych chwilach marzę o śmierci, ale czy na pewno? Życie jest przecież takie cudowne i tak naprawdę chciałabym jeszcze patrzeć na świat wokół”. 
Nie tylko sami chorzy cierpią w obliczu nieuleczalnej choroby. Rodzina odczuwa bardzo często podobne rozterki jak sam pacjent, podobnie też nie umie poradzić sobie z ciosem, jakim jest wiadomość o chorobie i niepewnych rokowaniach. Nadzieja umierającego pacjenta i jego rodziny wcale nie gaśnie ze wzrostem świadomości zbliżającej się śmierci, zmienia jedynie swój obszar. Ważne są wówczas wzajemne relacje.

\section{JUSTYNA (36 lat) $)^{42}$}

„Dwa tygodnie temu pożegnałam kogoś dla mnie szczególnego. Kogoś, kogo bardzo kochałam: moją starszą siostrę. Była zawsze dla mnie kimś szczególnym i choć to ona była starsza, to ja starałam się czuwać nad nią. Podobnie zresztą jak i rodzice, z którymi razem zamieszkała po rozwodzie. Pociechą dla niej był syn i praca. Kolejny cios otrzymała niespodziewanie, w grudniu ubiegłego roku: rak piersi. Była przerażona, podobnie jak wszyscy w rodzinie, a jednocześnie pełna nadziei i to do ostatniej chwili życia. W lutym zdecydowała się na operację. Nie chciała jednak przyjmować chemii. Korzystała z różnych osiągnięć medycyny alternatywnej, starając się dostrzec nawet najmniejszy znak poprawy. Nie zaprzeczała chorobie, wydawała się taka silna i zdolna pokonywać wszystkie przeciwności losu. Miała tysiące pomysłów i planów, chciała jeszcze tak wiele zrobić, no i jej syn ma zaledwie 15 lat.

To były dla nas wszystkich jakże trudne dni. Dziś nie ma jej z nami, ale cieszę się wspomnieniami ostatnich tygodni, gdyż choroba nie potrafiła jej złamać. Wierzyła, że to ona ją pokona. Mimo cierpienia i osłabienia, do ostatnich dni utrzymywała kontakt z innymi. Stać ją było na uśmiech i ogromne pokłady nadziei. To ona pocieszała nas słowami 'damy radę'. Niestety, nie udało się, więc ja bezradnie powtarzam 'to nie ten czas, to nie ta pora"”.

\section{PODSUMOWANIE}

Choroba, i to przewlekła, bywa przerażająca dla samego pacjenta, dla jego najbliższych i środowiska, w którym funkcjonuje. Jest jak długotrwały kataklizm, jak susza, która przez lata wyniszcza wszystko, w tym przypadku zdrowie i psychikę człowieka, tak zewnętrznie, jak i wewnętrznie. $Z$ jednej strony nadchodzi nieuchronne, co przekreśla wszystkie dotychczasowe plany życiowe, $z$ drugiej człowiek jest pełen nadziei na coś niespodziewanego, nieokreślonego. Jest oczywiście lęk, obecny w każdej chwili i tak trudny do opanowania, ale jest i zaprzeczenie temu, co złe oraz oczekiwanie na dobro. Jest i ból, i cierpienie. Bardzo często jest izolacja, samotność, zniechęcenie, odcięcie od bliskich i społeczeństwa.

42 Własny wywiad pogłębiony, niepublikowany, przeprowadzony w czerwcu $2017 \mathrm{r}$. 
W wielu przypadkach pojawia się poczucie klęski, determinujące konieczność przewartościowania życia i uświadomienia sobie, co naprawdę jest ważne. W końcu jest także nadzieja, niezwykły bodziec, który może pomóc nawet tam, gdzie medycyna bywa bezsilna. To nią karmi się osoba chora oraz jej otoczenie. To nadzieja nadaje często sens życiu chorym $\mathrm{i}$ ich bliźnim. Niech nie umiera nigdy.

\section{Bibliografia}

Bartoszek A., Człowiek w obliczu cierpienia i umierania. Moralne aspekty opieki paliatywnej, Księgarnia Świętego Jacka, Katowice 2000.

Brzezińska A., Społeczna psychologia rozwoju, Scholar, Warszawa 2000.

Chaplin J., McIntyre R., Hope: an exploration of selected literature, w: Palliative nursing: bringing comfort and hope, red. S. Kinghorn, R. Gamlin, Bailliere Tindall, Edinburgh 2001, s. 117-127.

Dziewulska J., Przeciw pustce i beznadziejności, „Magazyn Pielęgniarki i Położnej” 2000, nr 1-2, s. 24.

Frąckowiak T., O pedagogice nadziei. Fascynacje i asocjacje aksjologiczne, Wydawnictwo Naukowe UAM, Poznań 2007.

Gałkowski T., Nowe podejście do niepetnosprawności. Uporzadkowanie terminologiczne, „Audiofonologia” 1997, nr 10, s. 159-164.

Jan Paweł II, List do moich Braci i Sióstr - ludzi w podeszłym wieku. Stowa Ojca Świętego do ludzi starszych, Wydawnictwo M, Kraków 1999.

Kijak J., Szarota Z., Starość. Między diagnoza a działaniem, Centrum Rozwoju Zasobów Ludzkich, Warszawa 2013.

Kościelska M., Nadzieja w życiu ludzi, Difin, Warszawa 2013.

Kozielecki J., Psychologia nadziei, Wydawnictwo Akademickie Żak, Warszawa 2006.

Kwiatek P., Znaczenie i rozwój psychologii nadziei w ujęciu Charlesa Richarda Snydera, „Seminare” 2012, t. 31, s. 157-170.

Nosal Cz.S., Nadzieja, czas i heurystyka żagla, w: Człowiek wobec wyzwań i dylematów wspótczesności, red. E. Aranowska, M. Goszczyńska, Wydawnictwo Naukowe Scholar, Warszawa 2006, s. 228-243.

Praktyczny podręcznik psychoonkologii dorostych, red. M. Rogiewicz, Medycyna Praktyczna, Kraków 2015.

Rozporządzenie Ministra Zdrowia z dnia 22 listopada 2013 roku w sprawie świadczeń gwarantowanych z zakresu świadczeń pielęgnacyjnych i opiekuńczych w ramach opieki długoterminowej, Dz.U. 2013, poz. 1480, tekst jednolity Dz.U. 2015, poz. 1658.

Rychlicki Cz., Wiara, nadzieja, miłość wobec wieczności: z zagadnień wspótczesnej eschatologii, Płocki Instytut Wydawniczy, Płock 2001. 
Sikora P., Ośrodki wsparcia dziennego, w: Formy opieki, wychowania i wsparcia $w$ zreformowanym systemie pomocy spotecznej, red. J. Brągiel, S. Badora, Wydawnictwo Uniwersytetu Opolskiego, Opole 2005, s. 551-575.

Szatur-Jaworska B., Ludzie starzy i starość w polityce społecznej, Aspra-Jr, Warszawa 2000.

Tomaszewski T., Człowiek i otoczenie, w: Psychologia, red. T. Tomaszewski, PWN, Warszawa 1975, s. 13-36.

Twardowski J., Kilka myśli o wierze, nadziei i miłości, Święty Wojciech, Poznań 2006.

Ustawa z dnia 12 marca 2004 o pomocy społecznej, tekst jednolity Dz.U. 2015, poz. 163.

Ustawa z dnia 27 sierpnia 2004 roku o świadczeniach opieki zdrowotnej finansowanych ze środków publicznych, Dz.U. 2008, nr 164, poz. 1027 ze zmianami, tekst jednolity, Dz.U. 2015, poz. 581.

www.niepelnosprawni.pl/ledge/x/17796 (20.5.2017).

Uzar K., Fenomen nadziei w Wojciecha Chudego filozofii wychowania, „Roczniki Pedagogiczne" 37(2009), t. 1, s. 51-66.

Zavalloni R., Psychologia nadziei. Aby poczuć się zrealizowanym, Wydawnictwo Jedność, Kielce 1999.

Zych A.A., Człowiek wobec starości. Szkice z gerontologii społecznej, Śląsk, Katowice 1999.

\section{Streszczenie}

Człowiek w swym życiu doświadcza wielu różnych zdarzeń, wpływających znacząco na przebieg i jakość życia. Należy pamiętać, że zdrowie nie wyczerpuje listy trudnych sytuacji, które dotyczyć mogą ubóstwa, sieroctwa, przemocy w rodzinie, utraty bliskich osób, bezdomności, bezrobocia, niepełnosprawności, macierzyństwa, uzależnień czy ograniczenia wolności. W tym kontekście poruszono problematykę tzw. „radzenia sobie”, polegającego m.in. na umiejętności przystosowania się do kłopotów i zawirowań, jakie przynosi życie. W przypadku ludzi starszych takim zadaniem rozwojowym staje się np. akceptacja starości, uznanie swojej ułomności, obniżonej sprawności lub choroby. Nie jest to oczywiście łatwe, ale i w tym przypadku istotną rolę odgrywa nadzieja i przyjęcie odpowiedniej postawy wobec zaistniałych zjawisk. Nadzieja, niezwykły bodziec, który może pomóc nawet tam, gdzie medycyna bywa bezsilna. To nią karmi się osoba przewlekle chora przebywająca w ZOL oraz jej otoczenie. To nadzieja nadaje często sens życiu chorym i ich bliskim.

Słowa kluczowe: nadzieja, opieka, przewlekle chorzy, zakłady opiekuńczo-lecznicze 
Hope as a Major Factor of Chronic Patients Care at Healthcare Centres

\begin{abstract}
Summary
Every person experiences various situations in life which significantly influence its course and quality. It is worth remembering that health does not exhaust the list of the challenging circumstances that can relate to poverty, bereavement, family violence, the loss of the close ones, homelessness, unemployment, handicap, motherhood, addictions or freedom restrictions. Within this context, the question of so-called "doing-well", when one has to adapt to the life problems, was raised in this article. In the case of the elderly, one of such challenges is to accept one's old age and to acknowledge one's disabilities, decreased capabilities or illness. Obviously, it is not easy but the hope and the attitude of taking initiative in the changing circumstances play important roles. Hope can help even when medicine is hopeless. The chronic patient and those around him or her at the healthcare centre often relies on it. Finally, it is hope which frequently gives the meaning of life to the suffering people and their relatives.
\end{abstract}

Keywords: hope, care, chronic patient, healthcare institutions 